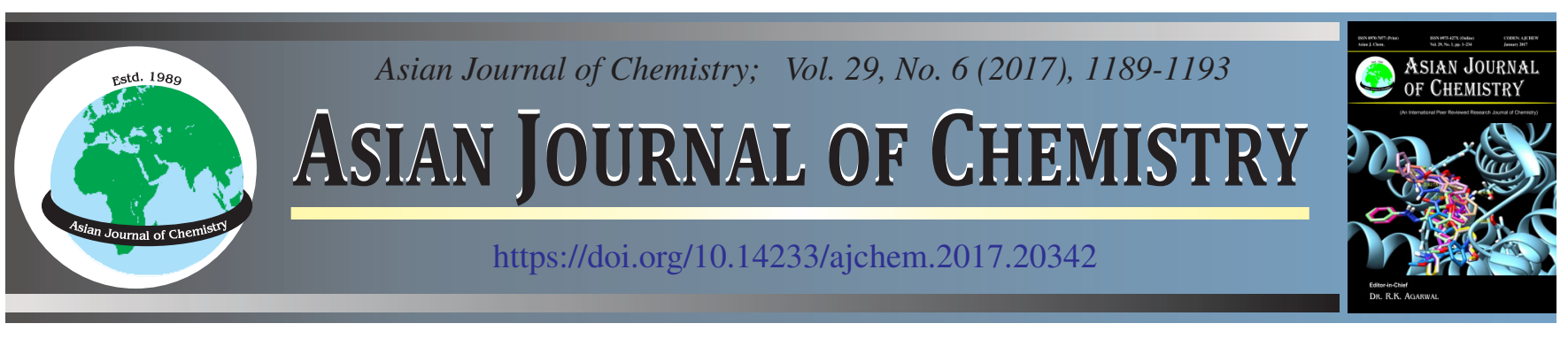

\title{
Variation of Shikimic Acid and Amino Acids in Tea Leaves as Influenced by Glyphosate Application
}

\author{
BANDANA $^{1}$ and NEELAM SHARMA ${ }^{2, *}$
}

${ }^{1}$ Central Potato Research Institute, Modipurum, Meerut-250 110, India

${ }^{2}$ Department of Agronomy, Forages and Grassland Management, College of Agriculture, CSK HPKV, Palampur-176 062, India

*Corresponding author: E-mail: sharma_neelam29@rediffmail.com

Received: 11 October 2016;

Accepted: 13 January 2017;

Published online: 10 April 2017;

AJC-18324

\begin{abstract}
A field experiment was conducted for consecutive two years to study the effect of glyphosate on biochemical attributes of tea. Experiment was laid out in randomized block design (RBD) consisted of four treatments viz. glyphosate $2.0 \mathrm{~kg} \mathrm{ha}^{-1}$, glyphosate $1.0 \mathrm{~kg}^{-1}{ }^{-1}$, glyphosate $0.5 \mathrm{~kg} \mathrm{ha}^{-1}$ and control. Tea samples were collected from the laid out experiment at fortnightly interval from imposed treatments for biochemical studies. Glyphosate at three levels of application i.e. $0.5,1.0$ and $2.0 \mathrm{~kg} \mathrm{ha}^{-1}$ decreased the values of all biochemical constituents i.e. total amino acids, amino acid profile, comprising six groups viz. aspartic acid, methionine, phenylalanine, leucine, theanine and glutamic acid, in tea leaves at zero day after application except shikimic acid content in tea leaves. The values of shikimic acid in tea leaves increased significantly on glyphosate application. In general, all biochemical constituents were influenced significantly upto 15 days after herbicide application except shikimic acid in tea leaves which were affected significantly upto 30 days after herbicide application. However, thereafter no significant effect was observed in any of biochemical constituents under study during both years.
\end{abstract}

Keywords: Glyphosate, Shikimic acid, Amino acid profile, Tea.

\section{INTRODUCTION}

India has unique distinction of being the largest producer and consumer of tea in the world. Indian tea industry produces 1000 million $\mathrm{kg}$ tea from an area of 5,78,458 hectares [1]. Tea industry in India has an annual turnover of 8 million U.S.\$ [2] and provides employment to million people. A mani-fold increase in production of tea in India is mainly attributed to efficient and integrated agricultural practices including efficient weed management practices. Weeds compete with crops for nutrient, sunshine and moisture. Besides reducing the yield, weeds also have adverse effects on tea viz. restricted branching, frame development in young tea, reduce plucking efficiency, harbour and serve as alternate host for many organisms including some important pests of tea. Thus, all these situations make it necessary to rely on herbicides for an effective and timely weed control. In tea plantations, use of herbicides as a tool for controlling weeds is very much popular and have been widely used ever since their introduction-primarily due to their cost-effectiveness, efficiency in controlling diverse weed flora and less labour intensiveness etc.

Glyphosate [N-(phosphonomethyl)glycine], a member of organophosphorus family is a recommended herbicide for weed control in tea [3]. It is a systemic herbicide that is absorbed by foliage and then trans-located throughout the plant via phloem. Once a herbicide molecule finds it place in living tissue of plant, a number of biochemical changes begin to take place. While herbicide molecule alters the metabolism of the plant, the latter degrades the structure and activity of herbicide by various biochemical processes. Depending upon the altered nature of herbicide metabolites in the plants, the growth and development of crop plant is affected in terms of both quality and quantity. Glyphosate has been proven as a potent and specific 5-enolpyruvyl shikimate-3-phosphate synthase (EPSPS) enzyme inhibitor. 5-Enolpyruvyl shikimate-3-phosphate synthase is a key enzyme of shikimate pathway. Glyphosate, a phloem-mobile herbicide is distributed symplastically along with other contents of sieve elements [4-8]. The phytotoxic action of a herbicide may affect one or more of the processes that maintain or regulate translocation and distribution of carbon among sinks and thereby affect its phloem-mediated distribution. Toxic effect of herbicide on photo-synthetic carbon fixation, allocation of both newly fixed and stored carbon, short-distance transfer and membrane transport by sieve elements interfere with export of both assimilated carbon and the herbicide. It binds with 5-enolpyruvyl shikimate-3- 
phosphate synthase thereby inhibiting plant amino acid biosynthesis [9]. 5-Enolpyruvyl shikimate-3-phosphate synthase is the only known enzyme target of glyphosate [10]. It affects many physico-chemical and physiological processes [11]. Glyphosate molecule binds outside the EPSPS active site unavailable to phosphoeonol pyruvate (PEP) [12]. It induces reduction in photosynthesis, degradation of chlorophylls, inhibition of auxin transport and enhancement of auxin oxidation. These aspect of mode of action are either a direct consequence of the blockage of shikimate pathway or as a result of feedback mechanisms [13]. Binding of glyphosate EPSPS has been shown to be competitive with phosphor enol pyruvate (PEP) and uncompetitive with respect to shikimate-3-phosphate [14]. The above details of shikimic acid biosynthetic pathway and mode of action of glyphosate via inhibition of this pathway are indicative of the fact that major biochemical quality attributes directly or indirectly are part of this pathway and may get affected adversely by glyphosate application leading to quality deterioration of tea.

\section{EXPERIMENTAL}

The samples of green tea shoots (two leaves and a bud) were randomly collected from research farm of Department of Tea Husbandry and Technology, CSK HPKV, Palampur at $2 \mathrm{~h}$ after herbicide spray and at 15 days intervals throughout the plucking season during both the years from tea field with four treatments (control, glyphosate $0.5 \mathrm{~kg} \mathrm{ha}^{-1}$, glyphosate $1.0 \mathrm{~kg} \mathrm{ha}^{-1}$ and glyphosate $2.0 \mathrm{~kg} \mathrm{ha}^{-1}$ ) replicated five times. The dried samples of green tea shoots were crushed into powder in a blender and stored in sealed polythene bags which were stored in a dessicator. These samples were used for biochemical constituents i.e. shikimic acid and total amino acids.

Preparation of standard curve for shikimic and estimation: Shikimic acid in dried tea sample was determined by the Mossor and Schramm method [15]. Stock solution (10 $\mu \mathrm{mol})$ of shikimic acid were dispensed in test tubes working solution in working range of 0.1 to 0.7 moles. Sulphuric acid ( $3 \mathrm{~mL}$ ) was added to each test-tube and the contents were mixed on vortex-mixer, $1 \mathrm{~mL}$ of 0.2 per cent aqueous solution of $p$-hydroxybenzaldehyde was added with constant stirring and heated for $1 \mathrm{~h}$. The absorbance of purple-violet coloured solution against blank was measured at room temperature at $590 \mathrm{~nm}$ on Thermospectronic UV-1. Dried tea sample (100 mg) was taken in $20 \mathrm{~mL}$ hot water and filtered through Whatman No. 1 filter paper. Filtrate was centrifuged for 15 min at 10,000 rpm. Supernatant $(100 \mu \mathrm{L})$ was taken (triplicate set) in testtubes. Shikimic acid in samples was measured by following the similar steps as given for standard curve.

Preparation of standard curve for total amino acid and estimation [16]: Standard curve was prepared by using methio-nine $(1 \mathrm{mg} / \mathrm{mL})$ in $80 \%$ acetone. Dried leaf sample (400 mg) was taken in centrifuge tube along with $80 \%$ acetone ( $3 \mathrm{~mL}$ ) and centrifuged for $10 \mathrm{~min}$ at $10,000 \mathrm{rpm}$. Concentrated super-natant was taken in $30 \mathrm{~mL}$ capacity separating funnel. Added to it $2 \mathrm{~mL}$ each of ethyl acetate, petroleum ether and $n$ butanol and collected aqueous layer in vial. The aqueous layer was loaded on to the Whatman No. 3 paper and were chromatographed using isobutanol/isopropanol/water/acetone (4:3:2:1 $\mathrm{v} / \mathrm{v})$ as the solvent front. Amino acids resolved into six zones were eluted following nin-hydrin spray (2\%) and colour was developed with ethanolic copper sulphate $(0.5 \%)$ and colour was read spectrophotometrically at $520 \mathrm{~nm}$ on Thermospectronic UV-I.

\section{RESULTS AND DISCUSSION}

Shikimic acid: The data regarding shikimic acid content as affected by different treatments is presented in Table-1. At zero day after herbicide application during first year a significant increase in shikimic acid in tea leaves was observed in glyphosate treatments viz. glyphosate $2.0 \mathrm{~kg} \mathrm{ha}^{-1}$, glyphosate $1.0 \mathrm{~kg} \mathrm{ha}^{-1}$ and glyphosate $0.5 \mathrm{~kg} \mathrm{ha}^{-1}$ over control. The values varied from 9.15 to $10.90\left(\mu \mathrm{mol} \mathrm{g}{ }^{-1}\right)$ with minimum and maximum values exhibited in control and glyphosate $2.0 \mathrm{~kg} \mathrm{ha}^{-1}$ treatment respectively. A similar behaviour of shikimic acid in tea leaves as depicted at zero day after herbicide application was observed at next plucking stage i.e. 15 days after herbicide application. Significantly higher values for shikimic acid in tea leaves were observed in glyphosate treatments over control. The values for shikimic acid varied from 8.33 to $9.94\left(\mu \mathrm{mol} \mathrm{g}{ }^{-1}\right)$ with minimum and maximum in control and glyphosate $2.0 \mathrm{~kg} \mathrm{ha}^{-1}$, respectively. At 30 days after herbicide application, shikimic acid values in tea leaves decreased during both the years. Glyphosate $0.5 \mathrm{~kg} \mathrm{ha}^{-1}$ was statistically at par with control and also obtained the numerically same values in the first year. Whereas for the second year of experiment, glyphosate $0.5 \mathrm{~kg}$ $\mathrm{ha}^{-1}$ being statistically alike with control obtained higher value of shikimic acid content in tea leaves and glyphosate $2.0 \mathrm{~kg}$ $\mathrm{ha}^{-1}$ was statistically similar with glyphosate $1.0 \mathrm{~kg} \mathrm{ha}^{-1}$ and recorded significantly lower value of shikimic acid content in tea leaves. These results clearly indicated that at 30 days after herbicide application, the effect of glyphosate on shikimic acid content in tea leaves decreased and this might be due to recovery of tea plant from the initial toxicity of herbicide or feedback inhibition. During both the years, at further stages of observations i.e. from 45 to 90 days after herbicide appli-

TABLE-1

EFFECT OF DIFFERENT TREATMENTS OF GLYPHOSATE ON SHIKIMIC ACID $\left(\mu \mathrm{mol} \mathrm{g} \mathrm{g}^{-1}\right)$ IN TEA LEAVES

\begin{tabular}{|c|c|c|c|c|c|c|c|c|c|c|c|c|c|c|}
\hline \multirow{3}{*}{ Treatments } & \multicolumn{14}{|c|}{ Days after herbicide application } \\
\hline & \multicolumn{2}{|c|}{0} & \multicolumn{2}{|c|}{15} & \multicolumn{2}{|c|}{30} & \multicolumn{2}{|c|}{45} & \multicolumn{2}{|c|}{60} & \multicolumn{2}{|c|}{75} & \multicolumn{2}{|c|}{90} \\
\hline & $\mathrm{I}^{\mathrm{st}}$ & $2^{\text {nd }}$ & $\mathrm{I}^{\mathrm{st}}$ & $2^{\text {nd }}$ & $\mathrm{I}^{\mathrm{st}}$ & $2^{\text {nd }}$ & $\mathrm{I}^{\mathrm{st}}$ & $2^{\text {nd }}$ & $\mathrm{I}^{\mathrm{st}}$ & $2^{\text {nd }}$ & $\mathrm{I}^{\mathrm{st}}$ & $2^{\text {nd }}$ & $\mathrm{I}^{\mathrm{st}}$ & $2^{\text {nd }}$ \\
\hline Control & 9.15 & 8.92 & 8.33 & 8.35 & 7.93 & 8.19 & 3.16 & 8.06 & 7.98 & 8.11 & 7.94 & 8.26 & 7.76 & 8.10 \\
\hline Glyphosate $0.5 \mathrm{~kg} \mathrm{ha}^{-1}$ & 9.49 & 9.51 & 9.29 & 9.25 & 7.93 & 8.14 & 3.04 & 8.06 & 7.91 & 8.20 & 7.88 & 8.29 & 7.76 & 8.00 \\
\hline Glyphosate $1.0 \mathrm{~kg} \mathrm{ha}^{-1}$ & 10.06 & 10.20 & 9.62 & 9.79 & 7.58 & 8.03 & 3.29 & 7.99 & 7.97 & 8.28 & 7.86 & 8.33 & 7.70 & 8.04 \\
\hline Glyphosate $2.0 \mathrm{~kg} \mathrm{ha}^{-1}$ & 10.90 & 11.12 & 9.94 & 10.28 & 7.86 & 8.01 & 2.98 & 8.04 & 7.95 & 8.04 & 7.86 & 8.25 & 7.73 & 8.08 \\
\hline
\end{tabular}


cation, the data on shikimic acid levels due to glyphosate application did not remain at elevated levels. In all the treatments, in general shikimic acid decreased from zero to 45 days after herbicide application and then increased upto 75 days after herbicide application. This trend may be due to seasonal variations of shikimic acid in tea leaves. However, during second year at 45 days after herbicide application a considerable decrease in shikimic acid values was noticed due to fungal infection caused by exobasidium vexans. Several workers $[16,17]$ have reported similar results due to fungal infection. During both years at zero and 15 days after herbicide application, direct dose-dependent behaviour of herbicide was observed i.e. with increase of glyphosate concentration shikimic acid accumulation increased. The maximum value of shikimic acid was exhibited by glyphosate $2.0 \mathrm{~kg} \mathrm{ha}^{-1}$ followed by glyphosate $1.0 \mathrm{~kg} \mathrm{ha}^{-1}$ and glyphosate $0.5 \mathrm{~kg} \mathrm{ha}^{-1}$. The trend obtained is in conformity with the studies carried out by other workers $[18,19]$ who reported that the shikimic acid accumulation was directly related to glyphosate concentrations.

Total amino acids: At zero day after herbicide application during first year of study, a sharp decline in total amino acid in tea leaves was noticed in all the three glyphosate treatments (Table-2) in the order i.e. glyphosate $2.0 \mathrm{~kg} \mathrm{ha}^{-1}\left(20.17 \mathrm{mg} \mathrm{g}^{-1}\right)$, glyphosate $1.0 \mathrm{~kg} \mathrm{ha}^{-1}\left(22.13 \mathrm{mg} \mathrm{g}^{-1}\right)$ and glyphosate $0.5 \mathrm{~kg}$ $\mathrm{ha}^{-1}\left(24.50 \mathrm{mg} \mathrm{g}^{-1}\right)$ as compared to control $\left(39.59 \mathrm{mg} \mathrm{g}^{-1}\right)$. At 15 days after herbicide application total amino acid in tea leaves decreased in all the treatments. The minimum accumulation of total amino acid in tea leaves was observed in glyphosate $2.0 \mathrm{~kg} \mathrm{ha}^{-1}\left(31.70 \mathrm{mg} \mathrm{g}^{-1}\right)$ and maximum was in control (41.52 $\left.\mathrm{mg} \mathrm{g}^{-1}\right)$. During the second year of experiment, a similar trend was observed at two plucking stages after herbicide application i.e. zero and 15 days. A decline in values of total amino acids was noticed in glyphosate applied treatments over control. Glyphosate at higher dose i.e. $2.0 \mathrm{~kg} \mathrm{ha}^{-1}$ recorded the significantly maximum reduction in amino acid followed by glyphosate $1.0 \mathrm{~kg} \mathrm{ha}^{-1}$ and glyphosate $0.5 \mathrm{~kg} \mathrm{ha}^{-1}$. A significantly higher accumulation of total amino acid in tea leaves was recorded in control at both the observation stages. No doubt, amino acid accumulation in glyphosate treated tea leaves was significantly reduced at both stages. However, sampling at 15 days after herbicide application recorded increase in accumulation of amino acid in all the treatments including control in comparison to sampling at zero day. At 30 days after herbicide application, different treatments did not influence the amino acid significantly in first year of study. During second year of study, significantly higher value for total amino acid in tea leaves was observed in glyphosate $0.5 \mathrm{~kg} \mathrm{ha}^{-1}(42.19$ $\left.\mathrm{mg} \mathrm{g}^{-1}\right)$ followed by control $\left(41.91 \mathrm{mg} \mathrm{g}^{-1}\right)$ and glyphosate 1.0 $\mathrm{kg} \mathrm{ha}^{-1}\left(41.60 \mathrm{mg} \mathrm{g}^{-1}\right)$. Whereas, glyphosate $2.0 \mathrm{~kg} \mathrm{ha}^{-1}$ resulted into lowest value of amino acid $\left(40.92 \mathrm{mg} \mathrm{g}^{-1}\right)$ in tea leaves. Irrespective of the treatments, a slight decrease in total amino acid values was observed at 45 days after herbicide application in first year. Significantly higher value of amino acid was noticed in control followed by glyphosate $0.5 \mathrm{~kg} \mathrm{ha}^{-1}$ and 2.0 $\mathrm{kg} \mathrm{ha}^{-1}$. However, glyphosate @ $1.0 \mathrm{~kg} \mathrm{ha}^{-1}$ resulted into significantly lowest value of amino acid in tea leaves. At 45 days after herbicide application, the data on total amino acids in tea leaves was found to be non-significant among different treatments in second year. The data among different treatments was recorded to be non-significant at further sampling stages viz. 60, 75 and 90 days after herbicide application during both years of experiment.

\section{Amino acid profile}

Aspartic acid group: A significant decrease for aspartic amino acid group in tea leaves was observed in all the glyphosate treatments as compared to control at zero day after herbicide application. Maximum decrease in aspartic acid group values in tea leaves was observed in glyphosate $2.0 \mathrm{~kg} \mathrm{ha}^{-1}(0.60 \mathrm{mg}$ $\mathrm{g}^{-1}$ in first year and $1.12 \mathrm{mg} \mathrm{g}^{-1}$ in second year) followed by glyphosate $1.0 \mathrm{~kg} \mathrm{ha}^{-1}\left(0.76 \mathrm{mg} \mathrm{g}^{-1}\right.$ in first year and $1.15 \mathrm{mg}$ $\mathrm{g}^{-1}$ in second year). However, during second year of experiment aspartic acid group values in tea leaves for glyphosate $2.0 \mathrm{~kg}$ $\mathrm{ha}^{-1}$ were statistically at par with glyphosate $1.0 \mathrm{~kg} \mathrm{ha}^{-1}$. A similar trend was observed at 15 days after herbicide application with minimum and maximum values exhibited by glyphosate $2.0 \mathrm{~kg} \mathrm{ha}^{-1}\left(0.55 \mathrm{mg} \mathrm{g}^{-1}\right.$ in first year and $1.03 \mathrm{mg} \mathrm{g}^{-1}$ in second year) and control $\left(1.18 \mathrm{mg} \mathrm{g}^{-1}\right.$ in first year and 1.65 $\mathrm{mg} \mathrm{g}^{-1}$ in second year). During first year of experiment (first year) all the three glyphosate treatments were statistically at par with each other. Whereas, in second year (second year) glyphosate $1.0 \mathrm{~kg} \mathrm{ha}^{-1}$ was statistically at par with glyphosate $0.5 \mathrm{~kg} \mathrm{ha}^{-1}$. It appears a slight toxicity is caused by glyphosate application which inhibits shikimate path way and ultimately decreases aspartic acid levels. The decrease in aspartic acid group values seems to be inversely correlated to herbicide dose clearly indicating that higher was the rate of herbicide application, more apparent was the reduction in aspartic acid levels and vice-versa. The data from 30 to 90 days after herbicide application revealed that different glyphosate treatments did not influence aspartic acid significantly

Methionine group: At zero days after herbicide application, during both years of study a significant decrease in methionine group of tea leaves over control was observed in all the three glyphosate applied treatments. Maximum decrease for methionine $\left(\mathrm{mg} \mathrm{g}^{-1}\right)$ amino acid group in tea leaves was

TABLE 2

EFFECT OF DIFFERENT TREATMENTS OF GLYPHOSATE ON TOTAL AMINO ACIDS $\left(\mathrm{mg} \mathrm{g}^{-1}\right)$ IN TEA LEAVES

\begin{tabular}{|c|c|c|c|c|c|c|c|c|c|c|c|c|c|c|}
\hline \multirow{3}{*}{ Treatments } & \multicolumn{14}{|c|}{ Days after herbicide application } \\
\hline & \multicolumn{2}{|c|}{0} & \multicolumn{2}{|c|}{15} & \multicolumn{2}{|c|}{30} & \multicolumn{2}{|c|}{45} & \multicolumn{2}{|c|}{60} & \multicolumn{2}{|c|}{75} & \multicolumn{2}{|c|}{90} \\
\hline & $1^{\mathrm{st}}$ & $2^{\text {nd }}$ & $1^{\text {st }}$ & $2^{\text {nd }}$ & $1^{\mathrm{st}}$ & $2^{\text {nd }}$ & $1^{\text {st }}$ & $2^{\text {nd }}$ & $1^{\text {st }}$ & $2^{\text {nd }}$ & $1^{\text {st }}$ & $2^{\text {nd }}$ & $1^{\text {st }}$ & $2^{\text {nd }}$ \\
\hline Control & 39.59 & 41.39 & 38.23 & 41.52 & 35.90 & 41.91 & 35.11 & 39.10 & 38.80 & 37.41 & 37.01 & 36.74 & 36.41 & 36.61 \\
\hline Glyphosate $0.5 \mathrm{~kg} \mathrm{ha}^{-1}$ & 24.50 & 26.71 & 30.63 & 35.59 & 36.11 & 42.19 & 34.68 & 39.14 & 38.81 & 37.33 & 37.06 & 36.89 & 36.44 & 36.52 \\
\hline Glyphosate $1.0 \mathrm{~kg} \mathrm{ha}^{-1}$ & 22.13 & 26.08 & 28.15 & 34.58 & 36.09 & 41.60 & 34.00 & 39.09 & 38.62 & 37.38 & 37.03 & 36.46 & 36.36 & 36.56 \\
\hline Glyphosate $2.0 \mathrm{~kg} \mathrm{ha}^{-1}$ & 20.17 & 25.72 & 24.14 & 31.70 & 36.08 & 40.92 & 34.16 & 39.12 & 38.43 & 37.32 & 37.03 & 36.55 & 36.26 & 36.62 \\
\hline $\mathrm{CD}(5 \%)$ & 0.43 & 0.14 & 0.47 & 0.35 & NS & 0.15 & 0.13 & 0.13 & NS & NS & NS & NS & NS & NS \\
\hline
\end{tabular}


recorded in glyphosate $2.0 \mathrm{~kg} \mathrm{ha}^{-1}\left(0.52 \mathrm{mg} \mathrm{g}^{-1}\right.$ in first year and $3.21 \mathrm{mg} \mathrm{g}^{-1}$ in second year). During first and second year of experiment glyphosate $2.0 \mathrm{~kg} \mathrm{ha}^{-1}$ being statistically at par with glyphosate $1.0 \mathrm{~kg} \mathrm{ha}^{-1}$ recorded significantly lower value for methionine group of amino acid. Almost a similar trend was observed in influencing the methionine amino acid group at 15 days after herbicide application with minimum and maximum values exhibited by glyphosate $2.0 \mathrm{~kg} \mathrm{ha}^{-1}(0.94$ $\mathrm{mg} \mathrm{g}^{-1}$ in first year and $2.77 \mathrm{mg} \mathrm{g}^{-1}$ in second year) and control (3.08 $\mathrm{mg} \mathrm{g}^{-1}$ in first year and $4.50 \mathrm{mg} \mathrm{g}^{-1}$ in second year) respectively. However, glyphosate $1.0 \mathrm{~kg} \mathrm{ha}^{-1}$ behaved statistically alike with lower dose of glyphosate i.e. $0.5 \mathrm{~kg} \mathrm{ha}^{-1}$ for the first year of experiment. At 30 days after herbicide application during first and second year of study, an increase in methionine $\left(\mathrm{mg} \mathrm{g}^{-1}\right)$ amino acid group was observed in all the treatments with lowest $\left(2.21 \mathrm{mg} \mathrm{g}^{-1}\right)$ in glyphosate $2.0 \mathrm{~kg} \mathrm{ha}^{-1}$ and highest $\left(3.86 \mathrm{mg} \mathrm{g}^{-1}\right)$ in control. Observations at further plucking stages i.e. $30,45,60,75$ and 90 days after herbicide application revealed that different treatments did not influence methionine amino acid group significantly.

Phenylalanine group: Immediately after herbicide application i.e. at zero day, a similar trend of decrease in phenylalanine was also observed as was recorded for aspartic acid group and methionine group in all the three glyphosate treatments. The values for phenylalanine based group of amino acid in tea leaves varied from 2.00 to $6.20 \mathrm{mg} \mathrm{g}^{-1}$ in first year and 3.72 to $5.80 \mathrm{mg} \mathrm{g}^{-1}$ in the second year with minimum and maximum values exhibited by glyphosate $2.0 \mathrm{~kg} \mathrm{ha}^{-1}$ and control respectively. During first year of experiment, treatment glyphosate $1.0 \mathrm{~kg} \mathrm{ha}^{-1}$ was statistically alike with glyphosate $0.5 \mathrm{~kg} \mathrm{ha}^{-1}$. However, in second year of experiment, all the three glyphosate treatments were statistically at par with each other. At 15 days after herbicide application, during both years of study glyphosate $2.0 \mathrm{~kg} \mathrm{ha}^{-1}\left(3.40 \mathrm{mg} \mathrm{g}^{-1}\right.$ in first year and $5.48 \mathrm{mg} \mathrm{g}^{-1}$ in second year) recorded least and control (6.18 $\mathrm{mg} \mathrm{g}^{-1}$ in first year and $6.26 \mathrm{mg} \mathrm{g}^{-1}$ in second year) obtained maximum value for phenylalanine based group of amino acids. During first year of study, glyphosate $0.5 \mathrm{~kg} \mathrm{ha}^{-1}$ was statistically at par with control, whereas for the second year of experiment, all the three glyphosate treatments were statistically at par with each other.It seems that glyphosate exerted toxic effect causing inhibition of the shikimic acid pathway which ultimately may affect the aromatic amino acid including phenylalanine. A perusal of the data at 30, 45, 60, 75 and 90 days after herbicide application revealed that different glyphosate treatments did not affect the phenylalanine group significantly.

Leucine group: At zero day after herbicide application a significant decrease in leucine group values in tea leaves was observed in all the three glyphosate treatments during both years of study. Among various treatments significantly higher value of leucine based amino group in tea leaves observed in control (11.79 $\mathrm{mg} \mathrm{g}^{-1}$ in first year and $12.36 \mathrm{mg} \mathrm{g}^{-1}$ in second year) whereas, glyphosate $2.0 \mathrm{~kg} \mathrm{ha}^{-1}\left(7.26 \mathrm{mg} \mathrm{g}^{-1}\right.$ in first year and $7.91 \mathrm{mg} \mathrm{g}^{-1}$ in second year) resulted into significantly lower values of leucine group followed by glyphosate $1.0 \mathrm{~kg} \mathrm{ha}^{-1}$ (7.48 $\mathrm{mg} \mathrm{g}^{-1}$ in first year and $8.03 \mathrm{mg} \mathrm{g}^{-1}$ in second year). During both years of study, all the three glyphosate treatments behaved statistically similar with each other. At 15 days after herbicide application, similar trend of decrease in leucine group in tea in all the three glyphosate treatments was recorded with minimum and maximum values possessed by glyphosate 2.0 $\mathrm{kg} \mathrm{ha}^{-1}\left(8.81 \mathrm{mg} \mathrm{g}^{-1}\right.$ in first year and $8.66 \mathrm{mg} \mathrm{g}^{-1}$ in second year) and control $\left(11.78 \mathrm{mg} \mathrm{g}^{-1}\right.$ in first year and $11.40 \mathrm{mg} \mathrm{g}^{-1}$ in second year) during both years of study. However in first year, glyphosate $2.0 \mathrm{~kg} \mathrm{ha}^{-1}$ behaved statistically similar with glyphosate $1.0 \mathrm{~kg} \mathrm{ha}^{-1}$ in decreasing leucine content in tea leaves. A sharp decline in leucine group of amino acid in tea leaves was noticed in glyphosate $2.0 \mathrm{~kg} \mathrm{ha}^{-1}$ followed by glyphosate $1.0 \mathrm{~kg} \mathrm{ha}^{-1}$ and glyphosate $0.5 \mathrm{~kg} \mathrm{ha}^{-1}$ at both zero and 15 days after herbicide application. The decrease in leucine amino acid values in tea leaves seems to be inversely related to herbicide doses i.e. at higher concentration of glyphosate, the accumulation of leucine amino acid was lower in tea leaves. The non-significant data from 30 to 90 days after herbicide application revealed that effects of herbicide was more prominent at earlier stage than at later stages and the plants recovered from the initial toxicity of the herbicide after 15 days of application.

Theanine: At zero day, a significant decrease in content of theanine group of amino acids in tea leaves was observed in glyphosate treatments i.e. glyphosate $2.0 \mathrm{~kg} \mathrm{ha}^{-1}$, glyphosate $1.0 \mathrm{~kg} \mathrm{ha}^{-1}$ and glyphosate $0.5 \mathrm{~kg} \mathrm{ha}^{-1}$ over control. The values of theanine content varied from minimum $8.79 \mathrm{mg} \mathrm{g}^{-1}$ in first year and $6.41 \mathrm{mg} \mathrm{g}^{-1}$ in second year to maximum $11.85 \mathrm{mg} \mathrm{g}^{-1}$ in first year and $12.45 \mathrm{mg} \mathrm{g}^{-1}$ in second year in glyphosate 2.0 $\mathrm{kg} \mathrm{ha}^{-1}$ treatment and control respectively. At 15 days after herbicide application, the values for theanine based amino acid increased irrespective of the treatments and the values ranged from 8.75 to $11.80 \mathrm{mg} \mathrm{g}^{-1}$ in year first year and 10.00 to 12.40 $\mathrm{mg} \mathrm{g}^{-1}$ in year second year with minimum and maximum theanine content recorded for glyphosate $2.0 \mathrm{~kg} \mathrm{ha}^{-1}$ and control, respectively. The extent of decrease in theanine amino acid group caused by glyphosate can be ascribed to concentration of applied glyphosate i.e. at higher the dose of glyphosate, more was the reduction in theanine contents of tea leaves. During both the years, at further stages of observations from 30 to 90 days after herbicide application, the data on theanine group levels was non-significant. This could be due to the reason that herbicide effect were temporary and plants recovered from the initial transitory toxicity with the passage of time.

Glutamic acid: During both years maximum decrease for glutamic acid group was recorded in glyphosate $2.0 \mathrm{~kg}$ $\mathrm{ha}^{-1}$ (1.00 $\mathrm{mg} \mathrm{g}^{-1}$ in first year and $3.35 \mathrm{mg} \mathrm{g}^{-1}$ in second year) followed by glyphosate $1.0 \mathrm{~kg} \mathrm{ha}^{-1}\left(1.42 \mathrm{mg} \mathrm{g}^{-1}\right.$ in first year and $3.40 \mathrm{mg} \mathrm{g}^{-1}$ in second year) and glyphosate $0.5 \mathrm{~kg} \mathrm{ha}^{-1}$ (1.80 $\mathrm{mg} \mathrm{g}^{-1}$ in first year and $3.48 \mathrm{mg} \mathrm{g}^{-1}$ in second year) respectively at zero day after herbicide application. Control recorded significantly higher value i.e. $4.24 \mathrm{mg} \mathrm{g}^{-1}$ in first year and $5.00 \mathrm{mg} \mathrm{g}^{-1}$ in second year of glutamic acid group in tea over all other treatments. During first year of experiment, glyphosate $2.0 \mathrm{~kg} \mathrm{ha}^{-1}$ was statistically at par with glyphosate $1.0 \mathrm{~kg} \mathrm{ha}^{-1}$. However, for the second year of experiment, all the glyphosate treatments behaved statistically similar with each other. In all the treatments, the content of glutamic acid group in general increased at 15 days after herbicide application as compared to zero days after herbicide application. During first year of study (first year), all the glyphosate treat- 
ments were statistically at par with each other whereas in second year (second year) glyphosate $1.0 \mathrm{~kg} \mathrm{ha}^{-1}$ behaved statistically alike with glyphosate $0.5 \mathrm{~kg} \mathrm{ha}^{-1}$. Control resulted into significantly highest values for both the years. This is attributed to the fact that decrease in glutamic acid is dosedependent i.e. higher dose of herbicide resulted into lower value of glutamic acid group indicating an inverse relationship. The above finding are contradictory to Hassan [20] who reported that high concentration of glyphosate increased glutamic acid and ammonia in lentils. This may be due to unknown pathways involved in different crops. The data on glutamic acid group was non-significant from 30 to 90 days after herbicide application. This indicates that plants might have recovered from the initial toxicity of herbicide application at later stages. The findings in different amino acids levels are in conformity with the facts that plants synthesize all of their essential amino acids and potentially numerous target sites exist in plants. Until now only three molecular sites have been shown to the primary site of action of commercially available herbicides [21] and glyphosate inhibits the biosynthesis of aromatic amino acids (phenylalanine, tryptophan and tyrosine) leading to reduced synthesis of proteins and secondary products [9].

\section{REFERENCES}

1. http://teaboard.gov.in/pdf/stat growers

2. http://www.siligurionline.com/industry/tea.htm.

3. F. Rahman, Two and a Bud, 38, 28 (1991).

4. J. Gorlach, H. Raesecke, D. Rentsch, M. Regenass, P. Roy, M. Zala, C. Keel, T. Boller, N. Amrhein and J. Schmid, Proc. Natl. Acad. Sci. USA, 92, 3166 (1995); https://doi.org/10.1073/pnas.92.8.3166.
5. F.T. Lichtner, Whats New Plant Physiol., 15, 29 (1984).

6. D.A. Kleier, Plant Physiol., 86, 803 (1988); https://doi.org/10.1104/pp.86.3.803.

7. S. Neumann, E. Grimm and F. Jacob, Biochem. Physiol. Pflanz., 180, 257 (1985); https://doi.org/10.1016/S0015-3796(85)80001-9.

8. M.T.C. Tyree, A. Peterson and L.V. Edgington, Plant Physiol., 63, 367 (1979); https://doi.org/10.1104/pp.63.2.367.

9. J.E. Franz, M.K. Mao and J.A. Sikorski, Glyphosate: A Unique Global Herbicide, ACS Monograph, American Chemical Society, Washington, DC, p. 189 (1997).

10. D.L. Siehl, Rev. Toxicol., 1, 37 (1997).

11. D.J. Cole, in eds: E. Grossbard and D. Atkinson, The Herbicide Glyphosate, Butterworth, London, pp. 48-74 (1985).

12. J.A. Sikorski and K.J. Gruys, Acc. Chem. Res., 30, 2 (1997); https://doi.org/10.1021/ar950122.

13. H.P. Singh and S.D. Ravindranath, J. Sci. Food Agric., 64, 117 (1994); https://doi.org/10.1002/jsfa.2740640117.

14. A.D. Dodge, Herbicide and Plant Metabolism, Cambridge University Press, pp. 97-112(1998).

15. T. Mossor and R.W. Schramm, Anal. Biochem., 47, 39 (1972); https://doi.org/10.1016/0003-2697(72)90276-X.

16. A. Gulati, A. Gulati, S.D. Ravindranath and A.K. Gupta, Mycol. Res., 103, 1380 (1999); https://doi.org/10.1017/S0953756299008941.

17. W.E. Dyer, J.M. Henstrand, A.K. Handa and K.M. Herrmann, Proc. Natl. Acad. Sci. USA, 86, 7370 (1989); https://doi.org/10.1073/pnas.86.19.7370.

18. K.A. Anderson, W.T. Cobb and B.R. Loper, Commun. Soil Sci. Plant Anal., 32, 2831 (2001); https://doi.org/10.1081/CSS-120000965.

19. T. Harring, J.C. Streibig and S. Husted, J. Agric. Food Chem., 46, 4406 (1998); https://doi.org/10.1021/jf9802124.

20. E.A. Hassan, Al-Azhar J. Agric. Res., 8, 403 (1988).

21. M.D. Devine, S.O. Duke and C. Fedtke, Physiology of Herbicide Action, Englewood Cliffs, NJ, Prentice Hall, pp. 252-263 (1993). 